\title{
Students with Severe, Permanent Disabilities and Their Educational Inclusion in Spain
}

\author{
Manuel López-Torrijo ${ }^{1} \&$ Santiago Mengual-Andrés ${ }^{1}$ \\ ${ }^{1}$ Department of Comparative Education \& History of Education, University of Valencia, Valencia, Spain \\ Correspondence: Manuel López-Torrijo, Avda. Blasco Ibáñez 30, Faculty of Philosophy and Educational \\ Sciences, 46010 Valencia, Spain. E-mail: lopezm@uv.es
}

Received: December 13, 2013 Accepted: January 14, 2014 Online Published: January 22, 2014

doi:10.5539/ies.v7n2p91

URL: http://dx.doi.org/10.5539/ies.v7n2p91

\begin{abstract}
This article analyses the educational inclusion of students with severe and permanent disabilities in the different autonomous communities of the Spanish State. After describing the Spanish socio-economic context, a comparative analysis is carried out based on the following indicators: the conception of severe, permanent disabilities; the regulation framework; responsibility of schooling and provision of services; identification and assessment of flaws; incidence in the population; curricular proposals (model and modalities of support); specific centers and units; human and material resources; the role of families and funding. The analysis of the implemented policies concludes by pointing out the challenges which should influence future improvements in order to accomplish real educational equality.
\end{abstract}

Keywords: inclusive education, special education, severe disabilities, educational policies, Spain

\section{Introduction}

Educational inclusion of students with special educational needs is one of the most fundamental reforms to have enriched the education system in recent decades. These reforms have made progress to achieving the goal of a complete, equitable education for all. Some significant milestones of that exciting process have been the proposal of "normalization" by Nirje (1969), Wolfensberger (1972) and Bank-Mikkelsen (1975); the "integration" extended throughout Europe by the Warnock Report (1978) and the current alternative of "educational inclusion" (e.g. Ainscow, 2007; Ainscow, Booth, \& Dyson, 2006; Arnaiz, 2003; Barton \& Roger, 1999; S. Stainback \& W. Stainback, 1999; Vega, 2000). We understand inclusive education as the exercising of the inalienable right to a full, quality education for all, which guarantees personal development and maximum social integration, taking diversity among students as a core idea within the curricular process.

Inclusive education implies and demands equality as a principle that ensures equal opportunities and no discrimination. It is developed in an everyday framework, whenever possible, and aims to achieve harmony, participation and cooperation within the educational community. It is adapted specifically to each person's individual needs. It advocates a meaningful, constructive, cooperative, reflexive learning process. Finally, inclusive education involves developing the social values of respecting, appreciating, cultivating and enjoying diversity and solidarity. This is why inclusive education develops a culture based on inclusion as the first, essential step towards a necessary goal, that of an inclusive society. Consequently, a real education must be inclusive; otherwise it is not an education at all.

Most governments have shown their support for this type of education, which subscribes to various international declarations (e.g. UN, 1971; UNESCO, 1990; UNESCO, 1994). Among these, we would like to point to the Convention on the Rights of Persons with Disabilities which was endorsed at the UN (2006) and UNESCO's 48 International Conference on Education (2008): "Inclusive Education: The Way of the Future" (Priestley, 2011).

The Spanish Committee of Representatives of the Disabled (CERMI) also gave its support in 2010 in celebration of the International Day of Persons with Disabilities by issuing a manifesto: "Por una educación inclusiva real y efectiva" (For a Real and Effective Inclusive Education) (CERMI, 2010). However, our study deals specifically with students who have disabilities, especially those that are severe and permanent.

A first conceptual approach is provided by the Declaration of Madrid of 2002. Its 400 participants demanded not to be treated as subjects deserving charity, as patients or dependents, or as segregated people, but as independent 
citizens and consumers who are conscious of their decisions and responsible for their own actions. (Congreso Europeo sobre Personas con Discapacidad, 2002)

Meanwhile, the World Health Organization's "International Classification of Functioning, Disability and Health" (WHO, 2001) avoids negative, segregating connotations of disability and emphasizes the importance of personal attitudes and contextual factors in how each person functions.

More recently, the UN's Convention on the Rights of Persons with Disabilities (UN, 2006, Preamble) reminds us in its introduction that:

Disability is an evolving concept and that disability results from the interaction between persons with impairments and attitudinal and environmental barriers that hinders their full and effective participation in society on an equal basis with others

The same document points out the diversity that exists among people with the same disability, the importance of their autonomy, their contribution to the sustainable development of society and the risks which result from poverty and higher levels of discrimination against adult and young women. It then goes on to define disability as:

Those who have long-term physical, mental, intellectual or sensory impairments which in interaction with various barriers may hinder their full and effective participation in society on an equal basis with others (UN, 2006, article 1).

Based on these considerations, we define students with severe, permanent disabilities as those whose disabilities have a degree of severity and duration which require exceptional measures-political, social, legal, educational, health-related and financial - in order to guarantee their inalienable right to an effective, quality education. Such severity implies health and social needs which need to be addressed together with the educational needs, so support should not be limited to health aspects or functional rehabilitation. The exceptional nature of these measures often requires specific centers of special education (SCSE) or specific units of special education (SUSE) within typical schools in rural or sparsely populated areas to address the difficulty of having specialized human and material resources in a typical educational environment. However, the final perspective of social integration for this type of student should always be borne in mind, which means moving towards the development of any activity, plan, or policy, in an environment which should be as normalized as possible. Other researchers have recently analyzed the same topic at a European level (e.g. Bjarnason, 2013; Fox, 2011; Kim, 2011; Kim \& Fox, 2011; López. 2009; López, 2008; Pearson, Watson, Stalker, Lerpiniere, Paterson \& Ferrie, 2011; Szecsi \& Giambo, 2007) and at an international level (Kim \& Fox, 2011). Our research aims to complement these studies through the presentation of the theoretical approach, the policies, the practice and the experience of Spain and its autonomous communities.

In this context, Spain provides schooling in specific centers of special education and specific units of special education for around $0.4 \%$ of its students with disabilities. It is one of the countries with a "single model" together with Italy, Greece, Portugal, Norway, Cyprus and Iceland, since less than $1 \%$ of students are educated in that type of modality.

Before our analysis, we would like to go through the main social indicators (Table 1) that explain and condition the educational support provided to these types of students in Spain. 
Table 1. Main social indicators in Spain in 2012

\begin{tabular}{|c|c|}
\hline Indicator & Description \\
\hline Official name & Kingdom of Spain \\
\hline Form of Government & $\begin{array}{l}\text { Constitutional monarchy. Two legislative chambers: Senate and } \\
\text { Congress of Deputies. }\end{array}$ \\
\hline Area & 505.957 square kilometers. \\
\hline Population & 47.190.493 inhabitants \\
\hline Density & 93.49 inhabitants $/ \mathrm{km}^{2}$ \\
\hline Languages & $\begin{array}{l}\text { Spanish, with four co-official languages in their respective } \\
\text { autonomous communities: Catalan in Catalonia and the Balearic } \\
\text { Islands, Basque in the Basque Country and Navarre, Galician in } \\
\text { Galicia and Valencian in the Valencian Community. }\end{array}$ \\
\hline Religion & $\begin{array}{l}\text { There is no official faith. } \\
\text { Catholics }>66.7 \% \\
\text { Non-religious }>32.1 \% \\
\text { Others }>1.2 \% \text {. }\end{array}$ \\
\hline Development index & 0.878 ( $23 \mathrm{rd}$ in the world). \\
\hline Doctors per 1,000 inhabitants & 4.8 \\
\hline Hospital beds per 1,000 inhabitants & 3.22 \\
\hline Computers per 1,000 inhabitants & 6.12 \\
\hline Unemployment rate & $24.34 \%$ \\
\hline Birth rate & 10.66 \\
\hline Mortality rate & 8.8. \\
\hline Child mortality rate & 3.39 \\
\hline Male life expectancy & 78.87 years \\
\hline Female life expectancy & 84.82 years \\
\hline Urban population & $79.1 \%$ \\
\hline Structure by age & $\begin{array}{l}<15 \text { years old: } 16 \% \\
16-64 \text { years old: } 67 \% \\
>65 \text { years old: } 17 \%\end{array}$ \\
\hline
\end{tabular}

\section{Educational Support Provided to Students with Severe, Permanent Disabilities}

In order to allow a comparative reading of our study with similar studies carried out in different socio-political contexts, we will focus our analysis on the following: conceptualization of severe, permanent disability; regulatory framework; responsibility of support; identification and assessment; effect on the population; schooling models and modalities, curricular proposals; SCSE and SUSE; human and material resources; role of families and funding.

\subsection{Conceptualization of Severe, Permanent Disabilities}

The current Spanish Organic Law of Education (LOE, 2006) introduces a new term in Title II: "students with specific needs of educational support" (SNES). That section is exclusively dedicated to "Equality in Education" and includes all students with special educational needs (SEN), with high intellectual abilities and with a late integration into the educational system. Article 71.2 also mentions students with specific learning difficulties or with personal or educational conditioning factors, whose needs are addressed through something called the "compensation of inequality in education". Students with disabilities are part of the first subgroup (SEN) and include "students who require, for a certain period or for their whole schooling time, a degree of support and specific attention because of a disability or a severe behavior disorder" (LOE, 2006, article 73). The LOE does not explicitly state anything else about students with severe, permanent disabilities, no doubt due to the application of general principles of normalization and inclusion (LOE, 2006, article 74). 


\subsection{Regulatory Framework}

It can be said that the recent process of educational integration/inclusion in Spain started with the PL 14/1970, General Law of Education and Financing of the Educational Reform-LGE-(LGE, 1970), which considered providing schooling to students with "deficiencies" in typical schools and creating SUSE within them, aimed at "mildly deficient students, whenever it is possible" (LGE, 1970, article 51).

Other important milestones in this process are: the founding of the National Institute of Special Education in 1975; the establishment of the Royal Board of Special Education in 1976; the creation of the National Plan for Special Education in 1978 by these two institutions; the "declaration of the rights of persons with disabilities" in article 49 of the Spanish 1978 Constitution; the proclamation of the PL 13/1982, Law for the Social Integration of the Disabled-LISMI-in 1982 (LISMI, 1982); the effective application of educational integration; the PL 8/1985, Organic Law of the Right to Education-LODE-(LODE 1985); the PL 1/1990, Organic Law of General Organization of the Educational System -LOGSE- (LOGSE, 1990); the adaptation of those principles to the new educational framework by the Royal Decree 696/1995 and the PL 10/2002, Organic Law of Quality in Education-LOCE-(LOCE, 2002).

The current Spanish educational system is regulated by the PL 2/2006, Organic Law of Education (LOE), which is a strong statement of intent for educational inclusion. Article 1 of Section 1 points out the ruling principles of the Spanish educational system:

(1) The quality of education of all students, regardless of their situation.

(2) Equality that should guarantee equal opportunities, educational inclusion and non-discrimination, acting as a remedial element for personal, cultural, economic and social inequities, especially those deriving from a disability.

(3) Transmitting and putting into practice social values that favor personal freedom, responsibility, democratic citizenship, solidarity, tolerance, equality, respect and justice, helping to overcome any type of discrimination.

(4) The conception of education as a permanent, lifelong learning process.

(5) Flexibility to adapt education to the diversity of students' aptitudes, interests, expectations and needs, as well as to any changes which might affect students or society.

"Attention to diversity" in Spain is thought of as a fundamental principle that should be applied to basic, compulsory education with "appropriate organizational and curricular measures" (LOE, 2006, articles 4.3, 19.1, 22.4 and 26.1). In Compulsory Secondary Education (ESO) references are made to measures such as:

Adaptation of the curriculum, integration of different subjects in one field, flexible groupings, group splitting, offering elective subjects, reinforcement programs and programs with personalized attention for students with specific needs for educational support (LOE, 2006, article 22.5 and article 24.8), as well as "specific solutions" for those students with learning disabilities, difficulties of integration, high intellectual abilities or disabilities (LOE, 2006, article 26.5).

In order to achieve this compulsory education, "programs of curricular diversification" are provided as an exceptional measure that makes it easier to access the Certificate of Compulsory Secondary Education (LOE, 2006, article 27). Likewise, there are repeated references to the fact that each school has the autonomy to adopt "measures of attention to diversity which are adequate for their students" (LOE, 2006, article 22.6). The education of adults responds to their different "abilities, needs and interests" and will provide adequate attention to those who have "specific educational support needs" (LOE, 2006, articles 67.5 and 7).

However, the clearest commitment of the LOE to inclusive education is the fact that it dedicates a whole Title, number II, to "Equality in Education". As we have stated above, Title II specifies the type of students who should be given support and guarantees the necessary means for them to achieve their maximum personal, intellectual, social and emotional development as well as the general objectives of the law itself. Emphasis is given to the importance of an early identification and intervention as well as an integral education based on the principles of "normalization and inclusion". The law pays special attention to parents, who are entitled to a free compulsory education for their children (LOE, 2006, article 88), participation in decisions related to the schooling and educational processes of their children, prior guidance and information when needed (LOE, 2006, article 71) and freedom to choose any type of public-funded school (LOE, 2006, article 84). Students with specific need of educational support should aim to be distributed equally and in a balanced way among public schools and private establishments financed with public funds. Disability is considered a priority criterion when 
choosing a school institution (LOE, 2006, article 84) and schooling for students with disabilities is especially guaranteed (LOE, 2006, articles 84 and 87).

The LOE guarantees that public administrations (the Ministry of Education at a national level and consejerias of education - regional ministries - in their respective autonomous communities) will provide qualified teachers of "each corresponding speciality" who should be appropriately trained. In addition, "school institutions will be appropriately organized and carry out any curricular adaptation or diversification needed". Cooperation among public administrations, public institutions and non-profitable private institutions will be promoted in order to provide the most suitable schooling (LOE, 2006, article 72).

The different autonomous communities with full educational competencies are currently undergoing a process of application and development of the LOE under the coordination of the Ministry of Education. Disparities within that process would require further, more specific research.

\subsection{Responsibility for Schooling and Provision of Services}

In Spain, the responsibility for schooling as well as the provision of educational services is shared by the Ministry of Education and the consejerias of education in its 17 autonomous regions - constitutionally named autonomous communities - , which have their own control over education.

Before the promulgation of the LOE, the different regions had started their own process to regulate support for the specific needs of educational support, as they were called at that time. Currently, the legislative development of the LOE regarding support to students with SNES includes programs promoted by the Ministry of Education: Program of Reinforcement, Orientation and Support (PROA); Prevention of Absenteeism and School Dropout (INTEGRA); Program for the Improvement of Educational Success (EXIT) and Programs of Initial Professional Qualification (PCPI). With regards to the autonomous communities, the development of the law is uneven, as shown in the list of regulations summarized in Table 2.

Table 2. Development of the LOE in the Spanish autonomous communities with regards to educational inclusion

\begin{tabular}{|c|c|c|}
\hline $\begin{array}{l}\text { AUTONOMOUS } \\
\text { COMMUNITY }\end{array}$ & $\begin{array}{lccc}\text { MAIN } & \text { AREAS } & \text { OF } & \text { THEIR } \\
\text { REGULATORY DEVELOPMENT }\end{array}$ & SPANISH FRAMEWORK DOCUMENT \\
\hline Andalusia & $\begin{array}{l}\text { High intellectual abilities, attention } \\
\text { to diversity and schooling reports. }\end{array}$ & $\begin{array}{l}\text { Instrucciones de 10.3.2011, (BOJA, 17.10.2011); } \\
\text { Instrucciones de 16.1.2007, (BOJA, 22.8.2008) }\end{array}$ \\
\hline Aragon & $\begin{array}{l}\text { Intercultural education, programs of } \\
\text { school harmony, compensatory } \\
\text { education, attention to diversity and } \\
\text { high intellectual abilities. }\end{array}$ & $\begin{array}{l}\text { Orden 6.11.2012 (BOA, 30.11.2012); Resolución } \\
\text { 10.2.2012; Resolución 26.10.2010; Resolución } \\
\text { 29.5.2007; Orden de 11.7.2007, (BOA, 22.8.2007). }\end{array}$ \\
\hline Asturias & $\begin{array}{l}\text { Programs of curricular } \\
\text { diversification and PROA. }\end{array}$ & 08, (BOPA \\
\hline Canary Islands & $\begin{array}{l}\text { Attention to diversity, compensatory } \\
\text { education, improvement of success, } \\
\text { home and hospital support, high } \\
\text { intellectual abilities, centres of } \\
\text { preferential support, support staff, } \\
\text { projects, financial support, awards. }\end{array}$ & $\begin{array}{llll}\text { Resolución } & 2060 / 12.04 .12 & \text { (BOC, } & 20.4 .2012) \\
\text { Decreto } 114 / 2011(B O C, & 11.5 .2011) & \text { Orden } \\
13.12 .2010 \quad \text { (BOC, 22.12.2010); } & \text { Resolución } \\
117 / 8.06 .2010 \quad \text { (BOC, 17.6.2010); } & \text { Resolución } \\
116 / 7.6 .2010 \quad \text { (BOC, 15.6.2010); } & \text { Resolución } \\
459 / 3.3 .2009 \text { (BOC, 27.3.2009) } & \end{array}$ \\
\hline Cantabria & $\begin{array}{l}\text { Attention to diversity, programs of } \\
\text { initial professional qualification. }\end{array}$ & $\begin{array}{l}\text { Orden EDU/42/2008,19.5.2008 (BOC, 30.5.2008); } \\
\text { Orden EDU/1/2008, 2.1.2008 (BOC, 7.1.2008) }\end{array}$ \\
\hline Castile and León & $\begin{array}{l}\text { Attention to students with specific } \\
\text { needs of educational support, late } \\
\text { integration and situations of } \\
\text { socio-educational disadvantage, } \\
\text { psychopedagogical evaluation and } \\
\text { schooling reports, significant } \\
\text { adaptations, house support. }\end{array}$ & 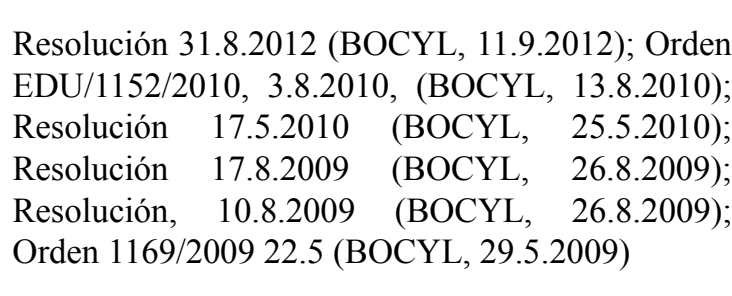 \\
\hline Castil & Attention to diversity, & $\begin{array}{lll}\text { Orden 30.4.2012 (DOCM, 14.5.2012); } & \text { Resolución } \\
22.2 .2012 & \text { (DOCM, 23.2.2012); } & \text { Resolución }\end{array}$ \\
\hline
\end{tabular}




\begin{tabular}{|c|c|c|}
\hline $\begin{array}{l}\text { AUTONOMOUS } \\
\text { COMMUNITY }\end{array}$ & $\begin{array}{lccc}\text { MAIN } & \text { AREAS } & \text { OF } & \text { THEIR } \\
\text { REGULATORY DEVELOPMENT }\end{array}$ & SPANISH FRAMEWORK DOCUMENT \\
\hline & harmony, educational success. & $\begin{array}{l}\text { 17.3.2011; Decreto } 3 / 2008, \\
\text { 11.1.2008). }\end{array}$ \\
\hline Catalonia & $\begin{array}{l}\text { Law of Education and school } \\
\text { harmony. }\end{array}$ & Decreto 279/2006 4.7 (DOGC, 6.7.2006) \\
\hline Valencian & & Resolución $\quad$ 12.11.2012 $\quad(\mathrm{DOGV}, 4.12 .2012) ;$ \\
\hline Community & $\begin{array}{l}\text { Support to individual differences, } \\
\text { special education, home and hospital } \\
\text { support, school harmony. }\end{array}$ & $\begin{array}{lclr}\text { Resolución } & 3.9 .2012 & \text { (DOGV } & \text { 7.9.2012); } \\
\text { Resolución } & 11.7 .2012 & \text { (DOGV, } & 1.8 .2012) \\
\text { Resolución } & 12.4 .2012 & \text { (DOGV, } & 23.4 .2012) \\
\text { Resolución 15.7.2011 (DOGV, 28.7.2011); Orden } \\
\text { 20.7.2011(DOGV, 1.8.2011) }\end{array}$ \\
\hline Extremadura & $\begin{array}{l}\text { Law of Education, school } \\
\text { absenteeism, teams of orientation } \\
\text { and early, specific attention. }\end{array}$ & $\begin{array}{l}\text { Orden } 11.9 .2007 \text { (DOE, 22.9.2007); Orden } \\
\text { 15.6.2007 (DOE, 10.7.2007); Orden, 24.2.2005 } \\
(\mathrm{DOE}, 15.3 .2005)\end{array}$ \\
\hline Galicia & $\begin{array}{l}\text { Attention to diversity, educational } \\
\text { support, high intellectual abilities, } \\
\text { educational success, Program } \\
\text { contract, initial professional } \\
\text { qualification, school dropout. }\end{array}$ & 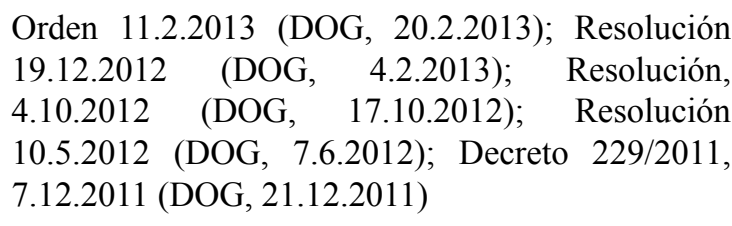 \\
\hline La Rioja & $\begin{array}{l}\text { Curricular diversification in } \\
\text { compulsory secondary education }\end{array}$ & $\begin{array}{l}\begin{array}{l}\text { Resolución } \\
\text { 29.3.2011) }\end{array} \\
\text { número }\end{array} 982$ 13.4.2012, (BOR, \\
\hline Madrid & $\begin{array}{l}\text { Special educational needs, high } \\
\text { intellectual abilities, late integration, } \\
\text { compensatory education, special } \\
\text { education. }\end{array}$ & $\begin{array}{l}\text { Orden, 18/2013, 9.1 (BOCM, 31.1.2013); } \\
\text { Resolución, 26.3.2012 (BOCM, 30.4.2012); Orden } \\
\text { 445/2009, 6.1 (BOCM, 19.1.2009); Resolución } \\
\text { 14.3.2007 (BOCM, 4.4.2007); Orden 70/2005, 11.1 } \\
\text { (BOCM, 21.1.2005) }\end{array}$ \\
\hline Murcia & $\begin{array}{l}\text { Attention to diversity, school } \\
\text { dropout and absenteeism, high } \\
\text { intellectual abilities, compensatory } \\
\text { education, late integration, support } \\
\text { in case of illness, school harmony. }\end{array}$ & 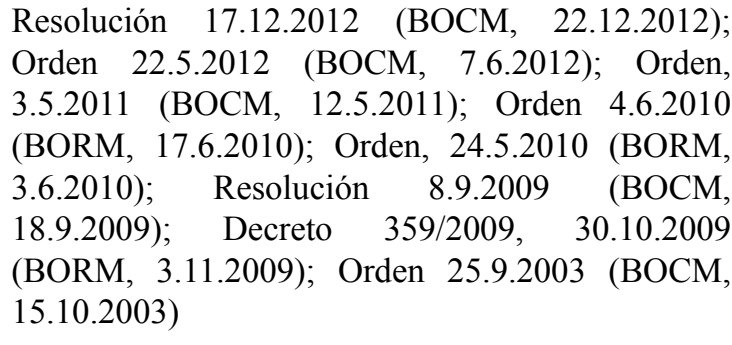 \\
\hline Navarre & $\begin{array}{l}\text { Attention to diversity, home and } \\
\text { hospital support, school harmony, } \\
\text { resource centres. }\end{array}$ & 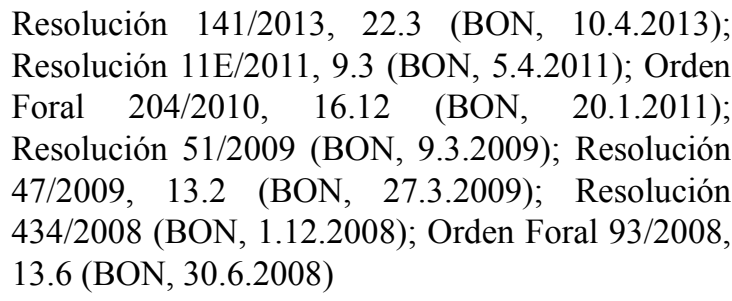 \\
\hline Basque Country & $\begin{array}{l}\text { Intercultural approach, attention to } \\
\text { diversity, immigrant students, school } \\
\text { harmony, home and hospital } \\
\text { support. }\end{array}$ & $\begin{array}{l}\text { Orden 29.5.2012 (BOPV, 11.6.2012); Resolución } \\
30.7 .1998 \text { (BOPV, 31.8.1998); Resolución } \\
\text { 24.7.1998 (BOPV, 31.8.1998); Decreto 118/1998 } \\
\text { (BOPV, 13.7.1998); Resolución 20.4.1998 (BOPV, } \\
\text { 26.5.1998) }\end{array}$ \\
\hline Ceuta and Melilla & $\begin{array}{l}\text { Intercultural approach, } \\
\text { compensatory education. }\end{array}$ & $\begin{array}{l}\text { Orden EDU/849/2010, de } 18.3 .2010 \text { (BOE, } \\
6.4 .2010)\end{array}$ \\
\hline
\end{tabular}

As stated in article 149.3 of the 1978 Constitution, the regulatory norms of the Ministry of Education, Culture and Sports are applicable to the territories where there are no autonomous decrees. 


\subsection{Identification and Assessment of Flaws}

The identification and the assessment of flaws is the first essential step in dealing with this type of student. Both activities are the responsibility of the Ministry of Health and the respective consejerias. The specialized teams that exist at public hospitals must apply the existing programs in a free and universal way. There are different universal perinatal screenings: congenital fetal anomalies, neonatal screening programs (e.g. HC, HFA, HSC, FQ, $\mathrm{Hb}$, amino acids, Gal, DB, MS/MS, etc), metabolic and auditory screenings, to name a few.

Medical attention is complemented by educational attention. The Ministry of Education's remit includes Teams of Educational and Psychopedagogical Orientation (EOEP) divided in: a) Teams of Early Attention (for children aged between 0 and 3-6 years), b) General Teams (for students of compulsory pre-school, primary and secondary education) and c) Specific Teams (providing support on specific disabilities to the other teams). EOEPs consist of qualified professionals: psychopedagogues, teachers of therapeutic pedagogy, hearing and language and social workers (also social educators in Andalusia) all of whom deal with a geographical area or a section of population. One notable absence is that of physiotherapists, psychometricians and neuropsychiatrists, who are usually present in other European countries. Some local governments compensate for certain deficiencies in the level of care provided with their own services. Apart from that, there are orientation departments in every secondary school providing those same services.

These teams carry out psychopedagogical evaluations in an interdisciplinary way and their approach is clearly pedagogical. According to the Orden EDU/849/2010 (article 48) by the Ministry of Education, psychopedagogical evaluation is understood as:

A process of compilation, analysis and assessment of students' relevant information and other elements which take part in the teaching-learning process in order to identify the educational needs of certain students who may show imbalances in their personal or academic development, with the objective of establishing the specific decisions which need to be taken so that those students are able to achieve their maximum personal, intellectual, social and emotional development, and to acquire basic skills.

This evaluation is shown in a psychopedagogical report, which will be carried out as soon as needs are detected for the student, at the beginning of their schooling or as they move from one stage of education to another.

There are some peculiarities in the way the 17 autonomous consejerias name and create these teams in terms of functions, programs and materials. Some of the most significant and representative ones are:

- Navarre, through its Resource Centre of Special Education of Navarre, provides specialized support on psychological disability, hearing and language, physical disabilities, visual disabilities, behavioral problems, high intellectual abilities, educational support, early attention and home and hospital support. They offer references on all topics related to diagnosis, orientation, support, resources and materials, publications, etc. Their web site (CREENA, 2013) is one of the most visited in Spain.

- The Canary Islands stands out for its units of orientation, hearing and language and social work. There are specific EOEPs on auditory and physical disabilities and support for pervasive developmental disorders.

- Murcia has developed valuable protocols for the assessment of students with autism and pervasive developmental disorders (CRM, 2013).

- Andalusia offers a computer application called "Séneca" to prepare psychopedagogical evaluation reports, schooling reports and significant curricular adaptations.

- Finally, Galicia offers valuable on-line documentation about audition and language, physical disabilities, sensorial disabilities, high intellectual abilities, conduct disorders, pervasive developmental disorders, intellectual disabilities, learning disorders and home and hospital support.

\subsection{Incidence in the Population}

In Spain, there are currently 7.928.727 people studying at a non-university level (MEC, 2009). Of those, 31.690 attend SCSE, which is $0.39 \%$ of the total (one tenth less than the previous year). They study in 485 educational centers: $40.4 \%$ are public and the rest are private.

The most updated full statistics on students with SNES offered by MEC (2012) are shown in Table 3. 
Table 3. Students with special educational needs in Spain. Academic year 2009-10

\begin{tabular}{|c|c|c|c|c|c|c|c|c|}
\hline \multicolumn{8}{|c|}{ Levels } & \multirow[b]{2}{*}{ Total } \\
\hline $\begin{array}{l}\text { Type of } \\
\text { centre }\end{array}$ & Pre-school & Primary & $\begin{array}{c}\text { Compulsory } \\
\text { Secondary }\end{array}$ & $\begin{array}{l}\text { Sixth } \\
\text { form } \\
\text { college }\end{array}$ & $\begin{array}{c}\text { Vocational } \\
\text { Training }\end{array}$ & PCPI & $\begin{array}{l}\text { Special } \\
\text { PCPI }\end{array}$ & \\
\hline $\begin{array}{l}\text { In public } \\
\text { centres }\end{array}$ & 11.381 & 42.942 & 25.330 & 754 & 1.137 & 1.820 & 1.169 & 84.533 \\
\hline $\begin{array}{l}\text { In private } \\
\text { centres with } \\
\text { public } \\
\text { funding }\end{array}$ & 2.869 & 10.914 & 9.724 & 109 & 301 & 477 & 1.360 & 25.754 \\
\hline $\begin{array}{l}\text { In private } \\
\text { centres with } \\
\text { no public } \\
\text { funding }\end{array}$ & 243 & 224 & 144 & 119 & 13 & 13 & 4 & 747 \\
\hline $\begin{array}{l}\text { Total of } \\
\text { students }\end{array}$ & 14.493 & 54.080 & 35.198 & 982 & 1.451 & 2.301 & 2.529 & 111.034 \\
\hline \multicolumn{9}{|c|}{ Total of students attending typical schools: 141.677} \\
\hline \multicolumn{9}{|c|}{ Total of students attending specific centres: 30.643} \\
\hline & \multicolumn{7}{|c|}{ Levels } & \multirow[b]{2}{*}{ Total $\%$} \\
\hline $\begin{array}{l}\text { Percentage } \\
\text { distribution }\end{array}$ & Preschool & Primary & $\begin{array}{l}\text { Compulsory } \\
\text { Secondary }\end{array}$ & $\begin{array}{l}\text { Sixth } \\
\text { form } \\
\text { college }\end{array}$ & $\begin{array}{c}\text { Vocational } \\
\text { Training }\end{array}$ & PCPI & $\begin{array}{l}\text { Special } \\
\text { PCPI }\end{array}$ & \\
\hline $\begin{array}{l}\text { In terms of } \\
\text { the total of } \\
\text { students }\end{array}$ & 0.8 & 2.0 & 2.0 & 0.2 & 0.3 & 13.2 & 88.2 & 1.5 \\
\hline $\begin{array}{l}\text { In public } \\
\text { centres }\end{array}$ & 1.0 & 2.4 & 2.1 & 0.2 & 0.3 & 3.3 & 88.6 & 1.7 \\
\hline $\begin{array}{l}\text { In private } \\
\text { centres with } \\
\text { public } \\
\text { funding }\end{array}$ & 0.6 & 1.4 & 1.8 & 0.2 & 0.3 & 2.9 & 88.0 & 1.3 \\
\hline $\begin{array}{l}\text { In private } \\
\text { centres with } \\
\text { no public } \\
\text { funding }\end{array}$ & 0.1 & 0.2 & 0.2 & 0.1 & 0.1 & 2.4 & - & 0.2 \\
\hline
\end{tabular}

Schooling data grouped by disability are shown in Table 4 . 
Table 4. Data of students with disabilities in Spain. Academic year 2009-10

\begin{tabular}{|c|c|c|c|c|c|c|c|c|c|}
\hline \multirow[b]{3}{*}{ Disability } & \multicolumn{9}{|c|}{ Type of centre } \\
\hline & \multirow[b]{2}{*}{$\mathrm{SC}$} & \multicolumn{7}{|c|}{ Centres with inclusive education } & \multirow[b]{2}{*}{ Total } \\
\hline & & Pre-school & Primary & CS & $\begin{array}{l}\text { Sixth-form } \\
\text { college }\end{array}$ & VT & PCPI & S-PCPI & \\
\hline Auditory & 559 & 14.493 & 54.080 & 35.198 & 982 & 1.451 & 2.301 & 2.529 & 6.666 \\
\hline Physical & 1.836 & 1.352 & 2.975 & 1,728 & 213 & 255 & 71 & 72 & 10.827 \\
\hline Psychological & 14.136 & 2.976 & 4.852 & 2.254 & 285 & 316 & 79 & 65 & 57.824 \\
\hline Visual & 201 & 4.929 & 27.592 & 21.041 & 84 & 571 & 1.693 & 1.914 & 2.753 \\
\hline $\begin{array}{l}\text { Pervasive } \\
\text { developmental } \\
\text { disorders } \\
\text {-Behavioural } \\
\text { disorders }\end{array}$ & 6.740 & 487 & 1.244 & 715 & 171 & 93 & 20 & 23 & 29.198 \\
\hline Multi-disabled & 6.257 & 4.039 & 15.566 & 8.605 & 205 & 187 & 391 & 205 & 3.709 \\
\hline Other & 914 & 710 & 1.851 & 855 & 24 & 29 & 47 & 193 & 6.666 \\
\hline Total & 30.643 & & & & & & & & 111.034 \\
\hline Total of students: & 141.677 & & & & & & & & \\
\hline
\end{tabular}

SC: Specific centres; CS: Compulsory Secondary; VT: Vocational Training; S-PCPI: Special PCPI.

Data grouped by gender are shown in Table 5

Table 5. Percentages of students with SNES compared to the total number of students grouped by gender. Academic year 2009-10

\begin{tabular}{|c|c|c|c|c|c|c|c|c|c|}
\hline \multicolumn{8}{|c|}{ Centres with inclusive education } & \multirow[b]{2}{*}{$\begin{array}{c}\% \\
\text { Total }\end{array}$} & \multirow[b]{2}{*}{$\begin{array}{c}\text { \% Total } \\
\text { ES }^{\mathrm{a}}\end{array}$} \\
\hline Gender & Pre-school & Primary & $\mathrm{CS}$ & $\begin{array}{c}\text { Sixth } \\
\text { form } \\
\text { college }\end{array}$ & VT & PCPI & S-PCPI & & \\
\hline Male & 1.0 & 2.5 & 2.4 & 0.2 & 0.3 & 3.1 & 88.1 & 1.1 & 2.3 \\
\hline Female & 0.6 & 1.4 & 1.5 & 0.1 & 0.2 & 3.4 & 88.5 & 1.4 & 1.4 \\
\hline
\end{tabular}

${ }^{\mathrm{a}} \%$ from the total number of students effectively attending school

SC: Specific centres; CS: Compulsory Secondary; VT: Vocational Training; S-PCPI: Special PCPI

Male students account for $63.5 \%$ and female students for $36.5 \%$. These percentages are practically the same as in typical schools (63.8 \% male and 36.2\% female), while students who attend SCSE are $62.2 \%$ male and $37.8 \%$ female (MEC, 2012).

\subsection{Model and Modalities of Support: Curricular Proposals}

After the psychopedagogical evaluation has been carried out, the schooling and rehabilitation can begin. This may take place in a typical school or in a specific unit or center depending on the degree of severity in the diagnosis.

As for the schooling models available, the general tendency is to provide educational support in a typical school as long as it is possible. The principles of "normality and inclusion" are a permanent characteristic of the LOE and they explicitly govern the schooling of students with SNES. However, schooling may be provided in "special education units or centers when the students' needs cannot be met by the provisions for diversity in typical schools". This type of schooling can be provided until the age of 21 (LOE, 2006, article 74). Schooling reports are revised every year. They are reversible and will always seek the students' most complete development, 
which includes as much social integration as possible.

The principle of flexibility — a characteristic of any inclusive program — has enabled other intermediate schooling models. The so-called mixed model combines different modalities: typical schools (part or full time); SCSEs (part or full time) and SUSEs (part or full time), provided especially in rural areas.

In the case of schooling modalities, different level and duration options are often combined: typical class with support within the class; typical class with support out of the class; part time; combined schooling (typical school as a reference with periods spent at specific centers or units); partial schooling: specific center as a reference combined with periods of time and/or subjects in a typical school; centers of preferential integration specialized in auditory or visual disabilities; alternative classrooms in rural areas; specific open classrooms for students with autism, other pervasive developmental or auditory disability; transition classrooms in typical schools (pervasive communication disorders); SUSE during compulsory secondary school with programs which are adapted to psychological disabilities; programs of transition towards adult life (PTVA); students with severe deficiencies in SCSE; programs of initial professional qualification; educational-therapeutic centers for students with severe psychiatric disorders cared for in psychiatric hospitals; hospital and home classrooms for students with illnesses not related to any disability; SCSE and resource centers. When these modalities are applied to a specific class within a typical school, flexibility can allow for even more nuances and options. As for the curriculum, it should always correlate to that of the typical class and its level, and any modification or proposal should be based on this point of comparison.

The LOE mentions "attention to diversity" as an essential principle, with individualization and prevention of learning difficulties being one of the main goals of primary education (LOE, 2006, article 19). As guiding measures for compulsory secondary education, the LOE proposes "the adaptation of the curriculum, the integration of different subjects in one field, flexible groupings, group splitting, offering elective subjects, reinforcement programs and programs with a personalized treatment" (LOE, 2006, articles 22.5 and 24.8). It does not propose regulating other specific solutions for supporting students with disabilities who may have special difficulties related to the learning process or integration in the typical activities of the school (LOE, 2006, article 26.5).

In practice, a wide variety of approaches and organizational and methodological proposals are being tested (Fernández, 2010). As general measures, the educational administrations insist upon the need for an equal distribution of students, an equal distribution of resources, the provision of professional and educational training, physical and technological adaptations, technical support, specific training for teachers and the need for pedagogical innovation, assessment and research. An essential element of the educational process is the Centre Educational Projects. These are the first concrete adaptations of the law's general objectives to a school's specific population as well as agreements made with the local educational community about the different parts of the curriculum. Consequent adaptations to the different stages and levels are the second step, leaving individual curricular adaptations (ACI) as the last resort.

Some of the most frequent methodological and organizational proposals we find are individual or group reinforcements (inside or outside of the educational center); curricular adaptations (of access, of the curriculum); continuing for an extra year in each educational cycle; group splitting; flexible groupings; educational compensation programs; EXIT and PROA programs; induction programs (PASEs); absenteeism reduction programs, school failure and school dropout prevention programs (INTEGRA); curricular diversification programs (PDCs); initial professional qualification programs. All of these allow for a possible adaptation to students with severe, permanent disabilities. The LOE pays special attention to the curricular diversification programs during compulsory secondary education (LOE, 2006, article 27). The assessment of learning should be continuous and global, and should have as a reference the specific needs or the individualized agenda of each student. Schooling in SCSEs and/or SUSEs is a measure which is especially suitable for students with severe, permanent disabilities, as will be explained in the following section.

\subsection{Specific Centers and Units of Special Education}

In rural areas, SCSEs and SUSEs are provided for students with special educational needs associated with severe, permanent disabilities mainly resulting from mental retardations and/or pervasive developmental disorders. These disabilities have required individualized significant curricular adaptations as a last resort, suggesting that the level of these students' adaptation and integration into typical schools would be minimal. Students with a specific type of disability (visual or auditory) can also be provided schooling in SCSEs in a combined modality.

The most up to date statistics show data for SCSE resources, which are compiled in Table 6. 
Table 6. Data for SCSEs in Spain. Academic year 2009-10

\begin{tabular}{lcccccc}
\hline Type of centre & $\begin{array}{c}\text { Amount of } \\
\text { centres }\end{array}$ & Teachers & $\begin{array}{c}\text { Amount of } \\
\text { units }\end{array}$ & Students & $\begin{array}{c}\text { A } \\
\text { Students/Unit }\end{array}$ & $\begin{array}{c}\text { A } \\
\text { Teachers/Unit }\end{array}$ \\
\hline $\begin{array}{l}\text { CEEE of special } \\
\text { education }\end{array}$ & 479 & 7.410 & 4.619 & 27.136 & 5.9 & 1.60 \\
$\begin{array}{l}\text { PUBLIC } \\
\quad \text { Consejerías of }\end{array}$ & 193 & 4.093 & 2.422 & 13.480 & 5.6 & 1.69 \\
$\quad$ education & 160 & 3.461 & 2.045 & 11.005 & 5.4 & 1.69 \\
$\quad$ Other ministries & 1 & 2 & 1 & 26 & 26 & 2.00 \\
$\quad$ Local governments & 32 & 630 & 376 & 2.449 & 6.5 & 1.68 \\
PRIVATE & 286 & 3.317 & 2.197 & 13.656 & 6. & 1.51 \\
\hline
\end{tabular}

In addition, there are 984 SUSEs in typical schools (910 public and 74 private or private with public funding). In these schools, 31.690 students are provided with some type of support.

There are some specific cases in the autonomous communities which are worth commenting on here. For example, the Canary Islands focus on the specific units located in typical schools. Known as enclave classes (aulas enclave), their priority is to enhance communication and favor the acquisition of everyday basic abilities and life skills. PTAVs are applied to students who are older than 14. The maximum allocation per group is five students, who have a specialist teacher trained in special education acting as a tutor and an educational assistant. There are a maximum of two enclave classes per school, in which educational support is provided, sharing as many activities as possible with the rest of the students in order to encourage inclusion.

In the autonomous community of Madrid, there are educational-therapeutic centers for students with severe psychiatric disorders (CIE-10ed. and DSM-IV). These are basically hospital classes in psychiatric hospitals with a 5-hour daily support. This requires the cooperation of educational and health services in order to minimize the impact of pathological processes on students, enabling them to develop the social abilities and skills necessary for their integration. These types of centers place special emphasis upon the cooperation and support of families.

With regards to the curriculum, current legislation states that SCSEs and SUSEs "will refer to the abilities established in the curriculum objectives for all fields of primary education, with the possibility of integrating abilities of other stages if students require". During the last years of education, emphasis should be placed upon abilities relating to professional development and social integration (MEC, 1996). SCSEs must carry out a specific curricular project which has to include this differential support to students through individualized significant curricular adaptations.

In recent years, SCSEs have reported several flaws: lack of official training regarding the organization and administration of their services; discrepancies between the existing curricular proposals and the real needs of students with severe, acute mental retardation — psychosis and autism —; and, finally, the need for curricular projects which are more adapted to the real needs of students. Some autonomous communities have started to provide assistance for these projects (Sainz, 1998).

Some theoretical proposals have been presented based on these approaches, such as the creation of an "area of personal independence" (Garrido, 2004) or alternative behavioral programs (Verdugo, 2000a, 2000b, 2000c). Likewise, some SCSEs have experimented with some isolated exemplary projects, such as the "Gloria Fuertes" Public Centre of Special Education in Andorra (Teruel), or the "Pérez Urruti" Centre in Churra (Murcia).

The process of restructuring SCSEs into resource centers is still in progress. These resource centers would be responsible for carrying out specific diagnoses; providing educational and rehabilitation support for typical schools; providing specific early attention as well as home and hospital support; providing specific resources, materials and methodologies; cooperating in the continuous training of professionals; facilitating occupational integration and support for adults with severe, permanent disabilities; and orientating and helping families.

\subsection{Human and Material Resources}

Table 6 shows the number of teachers who are responsible for the educational support of students with severe, permanent disabilities in Spain. Unfortunately, ratios vary according to location and conditions. Only the Valencian Community regulates these conditions of care. Professionals and families in other regions often report 
inadequate ratios and conditions.

If schooling is provided in SCSEs, the support teams are made up of school counsellors, technical community service teachers, teachers specialized in therapeutic pedagogy, teachers specialized in hearing and language; technical vocational training teachers, physical education teachers, religious education teachers, physiotherapists, psychometricians, III-E educational technicians and clerical employees. Table 6 shows that the group/classroom ratio for SCSEs is 5.9 students and the teacher/student ratio is 1.6.

In public SCSEs, basic training teams for transition towards adult life must be set up and led by the centers' coordinators.

It must be pointed out that professionals in these types of centers show a great involvement in the development of their activities, which is one the main guarantees of good care. This has been reported by their colleagues and by families themselves.

\subsection{Role of Families}

Families have been the actual promoters of educational inclusion in Spain. In the case of students with severe, permanent disabilities, this role is especially complex and difficult. The appropriate attitude from parents in accepting their child's disability in a realistic, constructive way will not only determine their own involvement but also their child's attitude towards their own disability.

Furthermore, children's special needs require specific abilities from parents who must take on all the functions their children require of them. That is why it is necessary to provide families with adequate psychopedagogical support, information and training until they are adequately prepared. The thriving association sector plays a vital role, something which becomes evident if we look into the dynamic activities of the various associations involved in the Spanish Committee of Representatives for the Disabled (CERMI) and its regional delegations.

The law recognizes parents' right to be informed about the educational decisions concerning their children and their right to participate in that process, although this aspect is not well defined for all situations. Consequently, parents have to approve their children's PDCs and, in some autonomous communities (the Valencian Community and Andalusia), they can choose (or subscribe to) the schooling model and the schooling center for their children. However, their participation in the provision of rehabilitation; external support; and socialization, autonomous-independent life, social and occupational integration programs, are not clearly defined. A good example of the current differences between declarations and real practice can be observed in the Decree 328/2010, 13.7.2010 (BOJA, 16.7.2010).

\subsection{Funding}

Spain has a funding model based on what Europe calls "contribution": the SCSE system is funded by the central or autonomous governments based on the number of students with severe, permanent disabilities. The indicators are the students themselves and the severity of their disabilities. Private centers with public funding are funded based on an economic module per unit or class. In the case of public schools, $93.3 \%$ offer free lunch service at school and $94.8 \%$ also offer school transport, while private schools offer $77.9 \%$ and $64.9 \%$ respectively.

In 2011, Spain spent 52.254.9 million euros on education, which is $4.79 \%$ of its GDP. Of that amount, $33.3 \%$ was allocated to pre-school, compulsory and special education. Specifically, 1.285.188,000 euros were allocated to 31.126 students in special education, which is $2.2 \%$ of the total educational spending. The Ministry of Education covers $0.2 \%$ of that amount, while the rest is paid for by the different autonomous communities.

In the academic year 2009-10, 56.658 scholarships were assigned to students of special education, with a total of 51.894 euros and an average of 967 euros per student, which means an increase of 50\% compared to the situation ten years ago.

Equally important is the economic support given to training, rehabilitation and extracurricular activities performed by non-profit associations. This is evident in the current demand for this type of economic support-also in Andalusia - where 7.020.863 euros have been allocated for the academic year 2012-13 (Orden 20.2.2012, BOJA, 15.3.2012)

\section{Conclusions, Discussion and Proposals}

The prioritization of inclusive education has led to a lack of recent studies on the group of students we are dealing with, who are generally schooled at SCSEs and SUSEs (Alberte, 1994; Font, Alomar \& Mas, 2004). In general terms, educational attention to students with severe, permanent disabilities has evolved towards a more social integration. This has resulted in important improvements within the political, organizational, didactic, professional, social and labor fields, such as their education in typical schools and a reduction of SCSEs and 
SUSEs or their restructuring into educational resource centers. Educational attention is unanimously considered to be of high quality in terms of the professionals' training and dedication and the provision of human and material resources.

Students with disabilities, their families, the professionals in charge of them and experts in the field all agree that further advances need to be made in the following fundamental areas if inclusive education is to be achieved (CERMI, 2010; Defensor del Menor de Andalucía, 2010; Junta de Andalucía, 2012; Pegalajar, 2011):

Regarding schools, general training of these students should be more functional. It should be based around a complete conception of their individuality, there should be diagnostic and educational protocols and emphasis should be placed on achieving their full personal autonomy and social and professional integration, rather than on inappropriate academic goals. The restructuring of SCSEs into educational resource centers is a process which has become more theoretical than real. Currently, students with behavioral problems - mainly students from compulsory secondary education - are being sent to SCSEs, whereas they should be given support in typical schools. Finally, improvements need to be made in institutional coordination at national, regional and local levels (health, education, social services, labor, economy and justice), as well as in personnel coordination (ordinary teachers, specialists, social educators; NGO professionals and volunteers, etc.) and particularly in coordination between the SCSEs and the typical schools.

Regarding teachers, there is an urgent need to guarantee a suitable initial and ongoing training of the various professionals working in education. The degree courses which have been created as a result of the Bologna process have caused, in most universities, a severe deterioration which can endanger education inclusion itself (Chiner \& Cardona, 2013; López, 2009; Moliner, Sales, Ferrández, \& Traver, 2011; Opertti \& Brady 2011).

With regard to families, it is essential to guarantee they receive information, training and psychological support in order to enable them to carry out the complex, difficult functions which their children's severe disabilities will demand from them throughout their whole lives.

If we look now into politics, it is urgent to develop national and regional regulations that apply the proposals made in the international declarations (UN 2006 Convention, UNESCO 2008 Conference, etc.), even the LOE itself. The current proposal made by the Ministry, which seeks to reform the LOE, is a serious threat to the inclusive education that has been achieved up to now, since emphasis is placed upon competitiveness and excellence.

Regarding the wider society, a realistic, positive, constructive, supportive attitude towards disabilities is an indispensable component of any educational action. Fostering this attitude in people with disabilities and their families as well as in professionals (educators, politicians) and eventually across society itself is an essential prerequisite for an inclusive society. Disability, possibly a co-vital component of humanity, contains some social values which are urgently necessary in today's world: effort; acceptance of what is different; respect, cultivation and enjoyment of diversity; empathy; resistance against any form of discrimination, inequality and marginalization; equality and solidarity. Only an education which accepts those values will be able to offer a complete education.

New rationalization measures for public spending brought in by the current Spanish government are also present in the new Organic Law for Improvement of Quality in Education (LOMCE, 2013) that was passed a few weeks ago. This new legislation is a visible set-back for the progress already made in Spain in promoting inclusive education as it entails a reduction in public funding for this purpose. This article has pointed out the aspects that must be guaranteed in order to further extend the inclusion of students with serious and permanent disabilities, showing the progress that Spain has made over the past twenty years. In the course of other parallel research, the authors are studying the prospective and future situation of students with less serious disabilities, who are currently educated in typical schools.

\section{References}

Ainscow, M. (2007). Taking an inclusive turn. Journal of Research in Special Educational Needs, 7(1), 3-7. http://dx.doi.org /10.1111/j.1471-3802.2007.00075.x

Ainscow, M., Booth, T., \& Dyson, A. (2006). Improving Schools, Developing Inclusion. New York: Routledge.

Alberte, J. R. (1994). Los centros especificos de special education:una realidad cuestionada. Madrid: ACK Servicios de Comunicación Galicia.

Arnaiz, P. (2003). La educación inclusiva: Una escuela para todos. Málaga: Aljibe.

Bank-Mikkelsen, N. E. (1975). El principio de normalización. Siglo Cero, 37, 16-21. 
Barton, L. E. N., \& Slee, R. (1999). Competition, selection and inclusive education: Some observations. International Journal of Inclusive Education, 3(1), 3-12. http://dx.doi.org /10.1080/136031199285147

Bjarnason, D. S. (2013). Inclusive education. Examining equity on five continents. Disability \& Society, 28(3), 428-431. http://dx.doi.org /10.1080/09687599.2013.764080

CERMI. (2010). Manifiesto del CERMI: Por una educación inclusiva real y efectiva. Retrieved from http://boletin.cermi.es/render.aspx?fichero $=625$

Chiner, E., \& Cardona, M. C. (2013). Inclusive education in Spain: how do skills, resources, and supports affect regular education teachers' perceptions of inclusion? International Journal of Inclusive Education, 17(5), 526-541. http://dx.doi.org /10.1080/13603116.2012.689864

Congreso Europeo sobre Personas con Discapacidad. (2002). La Declaración de Madrid 'No discriminación más acción positiva es igual a inclusión social'. Retrieved from http://www2.uca.es/huesped/down/declarmadrid.pdf

Constitución Española [Spanish Constitution]. (1978). Boletín Oficial del Estado, December 29.

CREENA. (2013). Centro de Recursos de Special education de Navarre. Departamento de Educación del Gobierno de Navarra. Retrieved from http://centros.educacion.Navarre.es/creena/

CRM. (2013). Attention to diversity. Retrieved from http://diversidad.murciaeduca.es

Fernández, J. M. (2010). Prácticas educativas eficaces ante la exclusión educativa. Archivos Analíticos de Politicas Educativas, 22(18), 1-22.

Font, J., Alomar, E., \& Mas, J. (2004). La evaluación de la calidad en los centros de special education. Una prueba piloto. Revista Española sobre Discapacidad Intelectual, 35(2), 37-44.

Garrido, J. (2004). Programación de actividades para Special Education. Madrid: CEPE.

Junta de Andalucía. (2012). Plan de actuación para la mejora de la atención educativa al alumnado escolarizado en centros específicos de educación especial en Andalucía. Andalucia: Junta de Andalucía.

Kim, E. (2011). 'Heaven for disabled people': Nationalism and international human rights imagery. Disability \& Society, 26(1), 93-106. http://dx.doi.org/10.1080/09687599.2011.529670

Kim, K. M., \& Fox, M. H. (2011). A comparative examination of disability anti - discrimination legislation in the United States and Korea. Disability \& Society, 26(3), 269-283. http://dx.doi.org/10.1080/09687599.2011.560371

LGE. (1970). Ley 14/1970, de 4 de agosto, General de Educación y Financiamiento de la Reforma Educativa. Boletín Oficial del Estado, August 6.

LOCE. (2002). Ley Orgánica 10/2002, de 23 de diciembre, de Calidad de la Educación. Boletín Oficial del Estado, December 24.

LODE. (1985). Ley 8/1985, de 7 de julio, reguladora del derecho a la educación. Boletín Oficial del Estado, July 4.

LOE. (2006). Ley Orgánica 2/2006, de 3 de mayo, de Educación. Boletín Oficial del Estado, May 4.

LOGSE. (1990). Ley 1/1990, de 3 de octubre, de Ordenación General del Sistema Educativo. Boletín Oficial del Estado, October 4.

López, M. (2008). La atención a alumnos con n.e.e. graves y permanentes. Un estudio comparado en Italia, Noruega e Islandia. In F. López-Noguero (Ed.), La educación como respuesta a la diversidad. Una perspectiva comparada (pp. 155-156). Sevilla: Universidad Pablo Olavide.

López, M. (2009). La inclusión educativa de los alumnos con discapacidades graves y permanentes en la Unión Europea. RELIEVE, 15(1), 1-20.

MEC. (2009). Estadística de las Enseñanzas no universitarias. Resultados detallados. Retrieved from http://www.mecd.gob.es/horizontales/estadisticas/no-universitaria.html

MEC. (2012). Datos y Cifras Curso Escolar 2010/2011. Ministerio de Educación. Retrieved from http://www.mecd.gob.es/dctm/ministerio/horizontales/prensa/documentos/2010/septiembre/datos-y-cifras-2 010-2011.indd.pdf?documentId $=0901 \mathrm{e} 72 \mathrm{~b} 803 \mathrm{eceed}$

Moliner, O., Sales, A., Ferrández, R., \& Traver, T. (2011). Inclusive cultures, policies and practices in Spanish compulsory secondary education schools: Teachers' perceptions in typical and specific teaching contexts. 
International Journal of Inclusive Education, 15(5), 557-572. http://dx.doi.org/10.1080/13603110903165158

Nirje, B. (1969). The Normalitation Principle and its human managemment implications. In R. Kugel, \& W. Wolfinsberger (Eds.), Changing Patterns in residential services fot the mentally Retarded (pp. 179-195). Washington: Presidents'on Mental Retardation.

Opertti, R., \& Brady, J. (2011). Developing inclusive teachers from an inclusive curricular perspective. PROSPECTS, 41(3), 459-472. http://dx.doi.org /10.1007/s11125-011-9205-7

Pearson, C., Watson, N., Stalker, K., Lerpiniere, J., Paterson, K., \& Ferrie, F. (2011). Don't get involved: an examination of how public sector organisations in England are involving disabled people in the Disability Equality Duty. Disability \& Society, 26(3), 255-268. http://dx.doi.org /10.1080/09687599.2011.560370

Pegalajar, M. (2011). Estrategias didácticas en enseñanza-aprendizaje de alumnos con discapacidad escolarizados en centros específicos de special education. Revista Educación Inclusiva, 4(3), 103-115.

Priestley, M. (2011). European yearbook of disability law (vol. 1). Disability \& Society, 26(2), 245-247. http://dx.doi.org /10.1080/09687599.2011.544065

Sainz, A. (1998). El proyecto curricular en los centros de educación especial. Vitoria-Gastériz: Servicio Central de Publicaciones del Gobierno Vasco.

Stainback, S., \& Stainback, W. (1999). Aulas inclusivas. Madrid: Narcea.

Szecsi, T., \& Giambo, D. A. (2007). Inclusive Educational Practices around the World: An Introduction. Childhood Education, 83(6), 338-341. http://dx.doi.org /10.1080/00094056.2007.10522946

UN (United Nations). (1971). Declaration on the Rights of Mentally Retarded Persons. United Nations: UN.

UN (United Nations). (2006). Convention on the Rights of Persons with Disabilities. United Nations: UN.

UNESCO. (1990). World Conference on EFA, Jontiem. Jomtien:UNESCO.

UNESCO. (1994). The Salamanca Statement and framework for action on special needs education. Paris: UNESCO.

UNESCO. (2000). The Dakar Framework for Action. Education for All: Meeting our Collective Commitments. Paris: UNESCO.

UNESCO. (2008). 48th session of the International Conference on Education. Inclusive education: The way of the future. Genova: UNESCO.

Vega, A. (2000). La educación ante la discapacidad. Hacia una respuesta social de la escuela. Valencia: Nau Llibres.

Verdugo, M. A. (2000a). PHS, Programa de habilidades sociales. Programas conductuales alternativos. Salamanca: Amarú Ediciones.

Verdugo, M. A. (2000b). POT, Programa de orientación al trabajo. Programas conductuales alternativos. Salamanca: Amarú Ediciones.

Verdugo, M. A. (2000c). PVD, Programa de habilidades de la vida diaria. Programas conductuales alternativos. Salamanca: Amarú Ediciones.

Warnock, M. (1978). Special Educational Needs. Report of comite of enquiry into the education of handicapped childrem and young people. London: Her Majesty's Stationery Office 1978.

WHO. (2001). International Classification of Functioning, Disability and Health. Retrieved from http://www.who.int/classifications/icf/en

Wolfensberger, W. (1972). The Principle of Normalitation in Human service. Toronto: National Institute on Mental Retardation.

\section{Copyrights}

Copyright for this article is retained by the author(s), with first publication rights granted to the journal.

This is an open-access article distributed under the terms and conditions of the Creative Commons Attribution license (http://creativecommons.org/licenses/by/3.0/). 